\begin{tabular}{ll}
\hline 原 \\
\hline
\end{tabular}

\title{
中小企業における結核患者の療養事情と職場復帰について
}

\author{
関西医科大学衛生学公衆衙生学数室 \\ 東田敏 夫, 田中美知子 \\ 健康保険長堀讋療所 \\ 石井秀利
}

\section{On the Medical Care for the Tuberculous and Rehabilitation in the Minor Enterprises}

\author{
Toshio Higashida, Michiko Tanaka \\ (Department of Hygiene and Public Health, Kansai Medical School) \\ Hidetoshi Ishii \\ (Nagahori Medical Office of Health Insurance)
}

A study is made of the medical care on social medical insurance basis for 658 tuberculous workers engaging in minor enterprises for $2-4$ years on mass examinations, the speciail reference to rehabilitation of the tuberculous. The results obtained are as follows :

1) About 70 per cent are treated with chemotherapy and 4 per cent with surgical treatment. The periods of chemotherapy for the most cases are short; less than 6 months for 28 per cent of the patients, less than one year for 50 per cent of them.

2) Forty per cent of the patients are away from work after the examination. Fifty per cent of the patients return to work after 6 months'rest.

3) Thirty per cent of the reposed lose their occupations. Half of the 30 per cent are due to "tuberculosis". Twenty per cent of the reposed are out of work and 30 per cent are looking for jobs.

4) About 70 per cent of the offices and factories have regulations for sick leave, which, however, allow a very short period mostly less than a year.

It seems that more facilities on a medical administration and social insurance basis are necessary in taking care of the tuberculous among the workers in medium and minor enterprises. 


\section{I 序論}

近来，企業体に和ける結核管理事業は，大企業に和い ては比較的順調にすすめられている傾向であるが，中小 企業では依然低調であることが指摘されている．著者ら はかねて，中小企業の結核の実態を調査し，それが中小 企業江括ける医務衛生管理上の欠宿と医療保障の不備と が相まつて，わが国に抽ける結核対策のみならず，学譈 者保健問題と㙏ける盲点であるととを報告しだ2)3)。

一方，結核化学療法の発達炕より，重症患者が減少し， 回復患者が増加し，てれらの患者の社会復帰が産業結核 そ护ける当面の問題となつている.さて, 結核帯患労働 者の職場復帰事情飞ついては, 職場復帰以前の療養状況 をきりはなして考吕れない。この事情は中小企業労働 者の場合はとくに重要である．われわれは中小企業検診 で発見された結核患者の療養状況と就労状態飞ついて調 查し，その動静を検討し，その対策にたいする指針をえ ることを試みた。

\section{II 調 查 方 法}

大阪府健康保険 $\mathrm{N}$ 診寮所几於て，1953,54,55年の 3 年 間飞括てなつた政府管掌被保険者を対象とする集団検診 （受検勤学者1953年 23,313 名, 54 年 33,562 名, 55年 20,980 名, 計77, 855名)火よつて発見された結核患者のうち981 名(338事業所) 飞ついて, 1958年 1 月, 検診後の療養及び 就業状態並びに退職または復職事情の調査をょこなつた。

調査成績を得た患者は213事業所，658名（男539名，

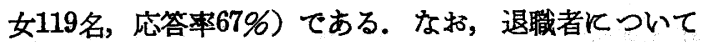
は個人宛飞退職後の状況調查を行なつた。

\section{III 成緌}

1. 集団検診で発見された結核患者の検診後の受㽷状 況

応答結核患者総数 658 名中，医療をうけたととある者 425 名 (72\%)，医療をうけなかつた者141名 (22\%) であつ ז.

$\mathrm{N}$ 診療所てて直接精密検診を実施した 391 名のうち, 活動性結核（岡氏病型II B，IV A, IV B の活動性及びVII 型）は 185 名である，そのうち受潦したもの 120 名 (65 \%), 受療しなかつたあの32名 (17\%) である.（第1四）

医療をうけた患者（425名）がうけた医療内容は，(第 1 表）化学療法をうけたもの72\%，結核外科滰法をうけ

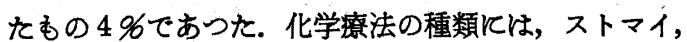
パス併用が最も多く47\%，次いでヒドラジッドを加えた

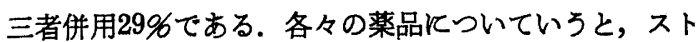
マイ使用 $83 \%$ ，パス使用 $85 \%$ ，ヒドラジッド使用は $44 \%$
第1表 結核患者がうけた化学察法の種類

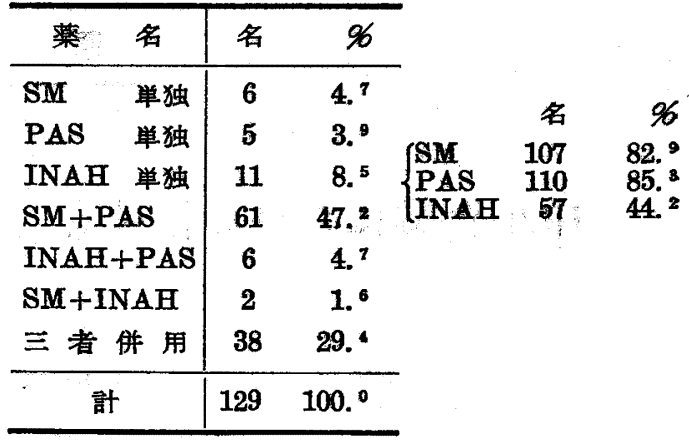

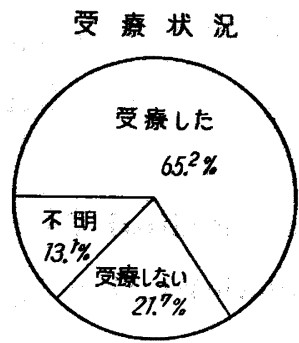

休養状 況

全患者 658 吕

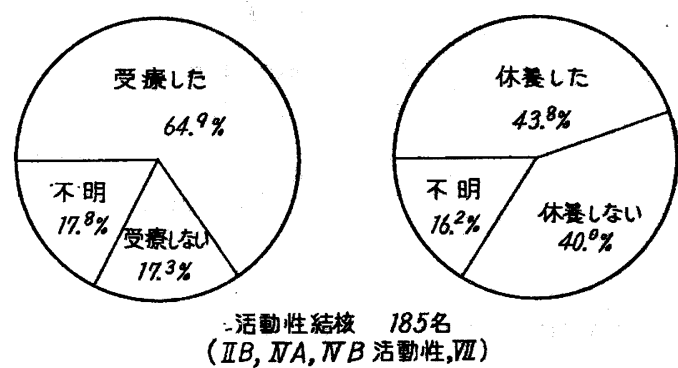

第1図集団検猃で発見された結核虫者の 検龍後の療養状況（2４ 年間）

であつた.

化学療法実施期間が判明している120名についていう と, 化学㙩法実施期間 6 力月以下 28\%である. すなわち，化学流法をうけた者の半数は 1 年以内で療している.開放性結核あるいは重症結核 (VII型)といえども長期任亘り化学療法をうけた者は少な い. (第 2,3 目)

\section{2. 結核患者の検匙後の休蒦状识}

結核患者総数について，休善したもの261名（40\%）， 休羲しなかつたもの327名 (50\%) であつた。活動性結 核患者では休養したもの81名（44\%)，休養しなかつた あの74名（40\%）であつた.（第 1 困）

休美期間が判明した結核患者 228 名について，3 月月 以下 $25 \% ， 6$ 力月以下の累計 $42 \% ， 1$ 年以下の累計 $65 \%$ 


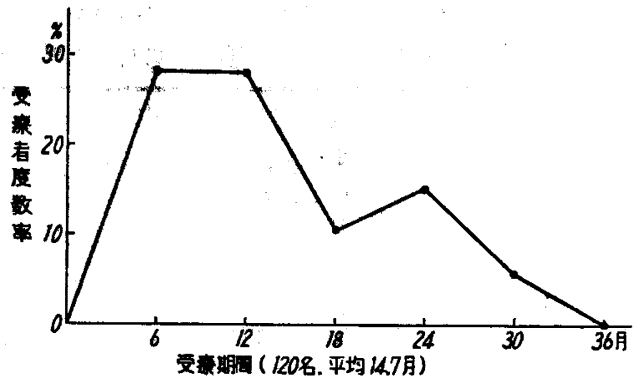

第2図 化学療法をちけた期間 (1953〜 57)

\begin{tabular}{|c|c|c|c|c|c|c|c|c|c|c|c|}
\hline $7 \mathbf{z}$ & 甲音 & $\begin{array}{ll} & 6 \\
\end{array}$ & $\frac{169}{912}$ & & 7 & 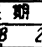 & $\frac{17}{172}$ & 427 & & 3 & Et \\
\hline WA & $14^{6}$ & $\cdots$ & 11 & & 11 & 11 & & & & ' & $10^{8}$ \\
\hline TB吕 & $15^{4}$ & י & ' "'III' & I & "1 & I & ' & ' & $i$ & ' & 17 \\
\hline NB传 & $12^{\prime}$ & 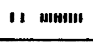 & 1 & 1 & i & 1 & $\because$ & & 1 & . & 22 \\
\hline VI & $6^{5}$ & ' & 1 & & & & & & & & 2 \\
\hline t & $110^{\circ}$ & & 11 & & & & & & & & 3 \\
\hline III & $12^{\circ}$ & ' & I & & & & I & & & & 3 \\
\hline 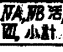 & $\mu^{\prime}$ & :"1!n! & 1 ( & I & ',' & & 1 & I & 1 & 11 & 30 \\
\hline st & $73^{3}$ & \begin{tabular}{l|l}
2 & 17 \\
$3^{5.5}$ & $24^{8}$
\end{tabular} & ${ }_{70}^{4} \quad 12$ & $?^{5}$ & $\begin{array}{l}5 \\
8^{8}\end{array}$ & $\stackrel{4}{2^{0}}$ & $\begin{array}{c}5 \\
8^{8}\end{array}$ & $l^{B}$ & $\frac{2}{3^{5}}$ & $\begin{array}{l}3 \\
5\end{array}$ & $\begin{array}{l}57 \\
1000\end{array}$ \\
\hline
\end{tabular}

第 3 図 病型別化学療法受療期間

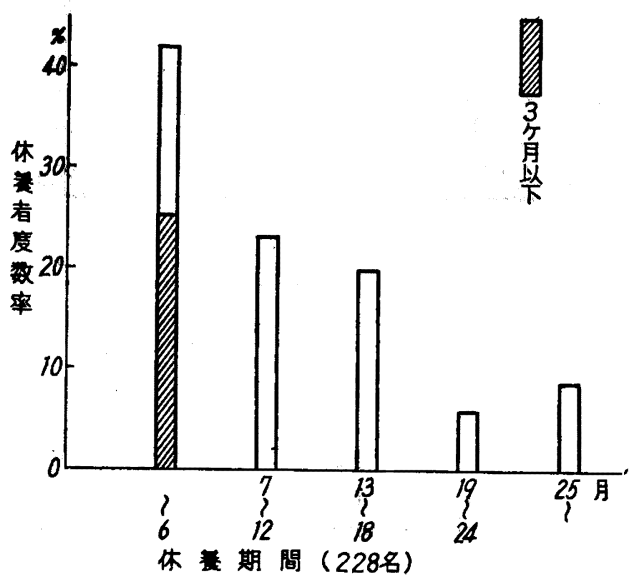

第4図 結核患者の休養期間

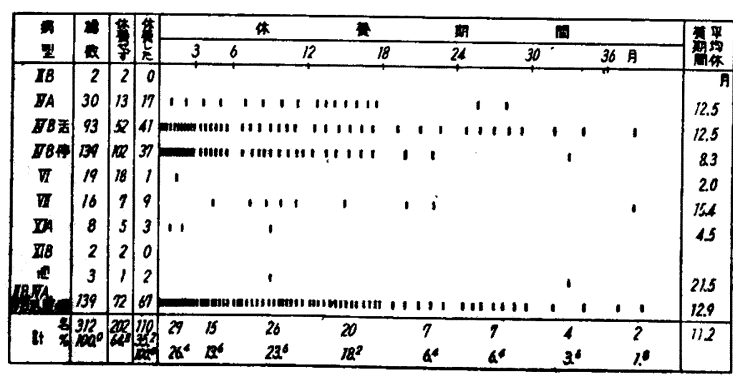

第 5 図結核患者の病型と休養期間
てある. すかわち，結核病休者の半数近くは半年以

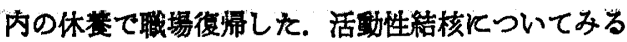
と，休菱 3 力月以下 $19 \% ， 6$ 力月以下の累計 $33 \%$, 1 年以下の累計 $55 \%$ であり，活動性結核患者の $1 / 3$ は 6 カ月以内で休意を打切り職場復带していた，（第 4, 5 四)

\section{結核患者の検匙後 $2 \sim 4$ 年間の維過}

1953年, 54年, 55年検埥後 $4 \sim 2$ 年後の1958年 1 月 までの経過については，企業体が散在するためこれ を把握することはすこふる困難であり，ようやく患 者または家族の応答をえたるの 265名についてみる と；死亡者11名，覀化者20名であつた。 その5ち， 活動性結核の悪化率は 2 4 年間に20\%である。こ れは患者の自訴によるるののみであるから，精査す ると「悪くない」すのの中にも悪化者が含まれると 思われる。なお，悪化者はいすれす就業をつつけ， あるいは復職後悪化した者であつた。

\section{3. 現在の在退職状況及ひ受療状況}

結核患者 658名の うち，2\%が死亡（内結核死亡 6 名, その他の死因 5 名), 在籍者は $72 \%$, 退職者 26\%. そのろち「結核による退職」と答光たすのは, 全体の $7 \%$ ，退職者の 13 である。但し検診後休養し

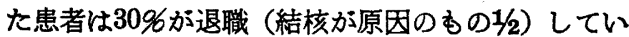
る. (第 2 表)

な扰1958年 1 月現在の状況は，658名中医療を万 けているすのは28\%（検診当時活動性結核は40\%が 医療をうけている)，医療内容は化学療法が82\%で ある.

また，在籍者 $74 \%$ （うち退職後再採用12名）退職 している者24\%（うち結核で退職したあのは退職者 の半数を占める).

退職者の現状は，(169名中応答数93名) 12\%が死 亡し，療養中か $10 \% ，$ 他の職業飞就業中が半数，失 業中20\%であつた. 就業中のうち満足をしていない 者をあわせて，退職者の30\%が現在適当な職業をむ とめている.（第 3 表）

\section{4. 中小企業における結核㾌善保障と結核回復者} 管理（第 4 表）

病気休職中の在籍保障を決めていない企業体は $1 / 3$, 決めている企業体の半数はその在籍保障期間が 1 年

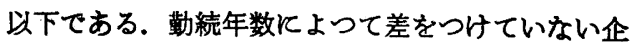
業体はその54\%，差をつけている企業体は46\%であ る. 企業体の経営規模別にみると，従業員数が少な い経営はど, 病休者にたいする在籍保障期間が短か い傾向がある. (第4 表) また製造業は，金融，販売 
第 2 表 結核患者の在退職状況

\begin{tabular}{|c|c|c|c|c|c|}
\hline & 総 & 在 㵝 & $\begin{array}{c}\text { 退 } \\
\frac{\text { 結榜に }}{\text { 因る }}\end{array}$ & $\mid \begin{array}{c}\text { 職 } \\
\mid \text { 他の理 } \\
\text { 昌 }\end{array}$ & 死 亡 \\
\hline 休葿した & $\begin{array}{l}263 \quad 44 .^{8} \\
100 . .^{\circ}\end{array}$ & $\begin{array}{l}180 \\
68 .^{4}\end{array}$ & $\begin{array}{c}31 \\
11 . .^{8}\end{array}$ & $\begin{array}{c}46 \\
17.5\end{array}$ & $\begin{array}{r}6 \\
2 .{ }^{3}\end{array}$ \\
\hline 休養せず & $\begin{array}{l}325 \\
100 .{ }^{\circ}\end{array}$ & $\begin{array}{l}265 \\
81 .{ }^{6}\end{array}$ & $\begin{array}{r}5 \\
1.5\end{array}$ & $\begin{array}{c}55 \\
16 .^{9}\end{array}$ & 0 \\
\hline 不 & 70 & 27 & 13 & 25 & 5 \\
\hline 合 計 $\begin{array}{l}\text { 名 } \\
\%\end{array}$ & $1000^{\circ}$ & $\begin{array}{r}472 \\
71 .{ }^{7}\end{array}$ & \begin{tabular}{|c|c}
49 \\
7.4
\end{tabular} & \begin{tabular}{|c|}
126 \\
19.2 \\
\end{tabular} & 11 \\
\hline
\end{tabular}

第 3 表 退職結核患者の現状

\begin{tabular}{|c|c|c|}
\hline 現 状 & 患者数 & $\%$ \\
\hline 結 核 死 & 6 & 6.4 \\
\hline 結核以外で死亡 & 5 & 5.4 \\
\hline 療 恶 中 & 9 & $9 .^{8}$ \\
\hline 就 業 中 & 43 & $46 .^{2}$ \\
\hline 満足している & 34 & $36 .{ }^{5}$ \\
\hline 満足していない & 9 & $9 .^{8}$ \\
\hline 失業 & 17 & $18 .^{3}$ \\
\hline 家事その他 & 13 & $14 .^{6}$ \\
\hline 計 & 93 & $100 .^{c}$ \\
\hline
\end{tabular}

（注 未解答 80 名志り）

業にくらべて保障規定を設けていない事業場が多い.

結核病休者復職規定を設けている企業体は19\%である. な招, 復職後の配置転換, 学働時間短察はすこぶる困 難な模様である.医務管理は，近辺の開業医者に嘱託し ているのが多い.

な打1954年実施した調査によると4)，結核患者の病気 休職期間に関する保障規定をすつ事業場は20\%にすぎず ことに100人未満の工場では房とんどない. また 1955 年 3 月現在の外来及び入院結核患者調査4)では，医療をう けている患者の半数は失業して拉り，休業中の患者では $73 \%$ が失業していた.つまり結核患者は病気休職すると 失業する可能性が大きいことをしめしている.

\section{IV 考察}

以上のごとき，政府管掌㯬康保険被保険者の集団検診 で発見された結核患者の検診後 $2 \sim 4$ 年間に括ける療養 事情と動静とついて調查した結果を概観して，問題点を さぐつてみよう.

まず，医療については「医者にかかつた」者が72\%で あり，従来わたくし達が調查した中小零細業従事者に括
第4表 中小企業に拉ける結核管理 イ. 結核病休者にたいする在籍保障期間（規模別）

\begin{tabular}{|c|c|c|c|c|c|c|c|}
\hline 企の & 調業 & 規 & 規 & \multicolumn{4}{|c|}{ 在籍保障期間内訳 } \\
\hline $\begin{array}{l}\text { 業規 } \\
\text { 体模 }\end{array}$ & $\begin{array}{l}\text { 查場 } \\
\text { 事数 }\end{array}$ & $\begin{array}{l}\text { 定 } \\
\text { な } \\
\text { し }\end{array}$ & $\begin{array}{l}\text { 定 } \\
\text { あ } \\
\emptyset\end{array}$ & $\begin{array}{l}6 \text { 以 } \\
\text { 力 } \\
\text { 月下 }\end{array}$ & $\begin{array}{l}1 \text { 以 } \\
\text { 年下 }\end{array}$ & $\begin{array}{l}1 \\
\text { 年月 } \\
6 \text { 昌 } \\
\text { 力年 }\end{array}$ & $\begin{array}{l}1 \\
\text { 年月 } \\
7 \text { 以 } \\
\text { 力上 }\end{array}$ \\
\hline $\begin{array}{l}50 人 \\
\text { 未満 }\end{array}$ & $\begin{array}{c}66 \\
100^{\circ}\end{array}$ & $\begin{array}{l}30 \\
46^{\circ}\end{array}$ & $\begin{array}{r}36 \\
54^{\circ} \\
100^{\circ}\end{array}$ & $\begin{array}{l}14 \\
38 .^{9}\end{array}$ & $\begin{array}{c}10 \\
27 .{ }^{8}\end{array}$ & $\begin{array}{l}2 \\
5.6\end{array}$ & $\begin{array}{l}10 \\
27 .{ }^{8}\end{array}$ \\
\hline $\begin{array}{c}50 \\
? \\
99\end{array}$ & $\begin{array}{c}41 \\
100^{\circ}\end{array}$ & $\begin{array}{l}16 \\
39 .\end{array}$ & $\begin{array}{r}25 \\
61.0 \\
100 .\end{array}$ & $\begin{array}{c}4 \\
16 . .^{0}\end{array}$ & $\begin{array}{c}9 \\
36 .^{\circ}\end{array}$ & $\begin{array}{c}4 \\
16 .\end{array}$ & $\begin{array}{c}8 \\
32 . .^{\circ}\end{array}$ \\
\hline $\begin{array}{c}100 \\
? \\
499\end{array}$ & $\begin{array}{c}68 \\
100 .\end{array}$ & $\begin{array}{l}20 \\
29 .\end{array}$ & $\begin{array}{c}48 \\
70.6 \\
100.0\end{array}$ & $\begin{array}{l}4 \\
8 .^{3}\end{array}$ & $\begin{array}{l}10 \\
20 .^{3}\end{array}$ & $\begin{array}{l}10 \\
20 .^{8}\end{array}$ & $\begin{array}{l}24 \\
50 .{ }^{\circ}\end{array}$ \\
\hline $\begin{array}{l}500 \\
\text { 以上 }\end{array}$ & $\begin{array}{c}14 \\
100 .\end{array}$ & 0 & $\begin{array}{c}14 \\
100 . \\
100 .\end{array}$ & 0 & $\begin{array}{c}3 \\
21.4\end{array}$ & $\begin{array}{c}2 \\
14 .^{3}\end{array}$ & $\begin{array}{c}9 \\
64 .^{3}\end{array}$ \\
\hline 計 & $\begin{array}{l}189 \\
100 .\end{array}$ & $\begin{array}{l}66 \\
34 .{ }^{9}\end{array}$ & $\begin{array}{r}123 \\
65.1 \\
100 .\end{array}$ & $\begin{array}{l}22 \\
17 .{ }^{9}\end{array}$ & $\begin{array}{l}32 \\
26 .^{\circ}\end{array}$ & $\begin{array}{c}18 \\
14 .^{6}\end{array}$ & $\begin{array}{l}51 \\
41 .{ }^{5}\end{array}$ \\
\hline
\end{tabular}

ロ.復職に関する規定

\begin{tabular}{|c|c|c|c|}
\hline $\begin{array}{l}\text { 会 } \\
\text { 社 } \\
\text { のに } \\
\text { 規よ } \\
\text { 準る }\end{array}$ & $\begin{array}{c}\text { 主診 } \\
\text { 治断 } \\
\text { 医に } \\
\text { のょ } \\
\text { る }\end{array}$ & $\begin{array}{l}\text { 特 } \\
\text { に } \\
\text { きい } \\
\text { めな } \\
\text { てい }\end{array}$ & 計 \\
\hline 41 & 90 & 82 & 213 \\
\hline $19 .^{3}$ & $42 .^{2}$ & 38.5 & $100 . \%$ \\
\hline
\end{tabular}

八. 復 職 配 置

\begin{tabular}{|c|c|c|c|c|c|}
\hline \multicolumn{3}{|c|}{ 配 置 䎐 換 } & \multicolumn{3}{|c|}{ 労働時:間短縮 } \\
\hline $\begin{array}{c}\text { あ } \\
\text { り }\end{array}$ & な & 訫 & $\begin{array}{c}\text { あ } \\
\eta\end{array}$ & $\begin{array}{l}\text { な } \\
\text { L }\end{array}$ & 計 \\
\hline 56 & 116 & 172 & 60 & 85 & 145 \\
\hline $32 .^{6}$ & 67.4 & $1000^{\circ}$ & $41 .{ }^{4}$ & $58 .^{6}$ & $100 .{ }^{\circ} \%$ \\
\hline
\end{tabular}

二. 採用時検䧐

\begin{tabular}{cc|c}
\hline $\begin{array}{c}\text { あ } \\
\text { し }\end{array}$ & $\begin{array}{c}\text { な } \\
\text { し }\end{array}$ \\
\hline 153 & 39 & 192 \\
$79 .^{7}$ & $20 .^{3}$ & $100.0^{\circ} \%$ \\
\hline
\end{tabular}

ける成績よりはやや良好である，いずれも健康保険被保 険者であることと, 検診後の処置の仕方などが関係する と思われるが，それであな怙，22\%が「医者化かかつた ことがない」とこたえている点は注目すべきである．医 療内容は，さすが沉と大部分（受療者の72\%) が化学 
療法をうけているか，問題は化学濝法をうけていた期間 がすとぶる短かいことである. 6 力月以下が28\%，6力 月以上 1 年以下が2896い弓状龍は，職場復州について， 今月の結核病学が要求している術式 ${ }^{5) 6)}$, 「化学療法を相 当期間にわたり，少なくとす 1 年以上，つつけ，活動性 病像がなくなつて後 3 カ月間は悪化がないととをたしか めて, つまり Target Point 飞達した後, 化学療法をう ち切り，作業療法またはそれと類する観察期間を経て， もとの職場に帰すという術式」からは，程遠い事実とい わねばならない，このととは，結核患者の約 $50 \%$ が全く 休養せず㗢きながら手当をうけている実情を考えると， いつそう重要な意味をむつ.

病気休業者が少ない理由の第一は，休業するさい給付 される健康保険の傷病手当金が少額にすぎ，生計をおび やかすためであろう. アンケートの成績もとれをみとめ ている.ささらにまた，病気休業が失業導びくという事 情も関係があろう．休養期間がみじかいことには，この 両者が要因となつている.「働きながら医療をうける」 傾向は，このような現実問題を背景としているのをみの がしてはならない. 少なくとも化学療法継続期間がこの ように短かいことは, 病状の悪化, 再発をまねくものと して注意される必要がある.

中小企業に括いてみられる結核患者の検診後の療養指 導や医療の不足は，一つは今日の結核対策事業の欠陷や， 医療保障制度の矛盾飞基因しているが，また職場におけ る医務衛生管理の体制が整つていないためであある.さ しあたり，その対策として中小企業が協同の医務健康管 理の施設と組織をむつことを考虑されてよい，他方にお いて, 政府管掌被保険者がうける健康保険の傷病手当金 が低額にすぎ，組合管掌にくらべて平均して半額に近い 事情もみのがされてはならない. このことは，むともと 中小企業に括ける低貨金を基因として括り，その解決は 容易ではなかろう。これもさしあたりは，多くの健康保 険組合では実施されている療善扶助費の附加給付を考兄 る必要があるだろう。

さて，患者の $26 \%$ か， $2 \sim 4$ 年間に退職したことも意 味が深い. 退職理由の真偽については即断するととはさ けねばなるまいが，結核を理由として退職した者は半数 に満たない. 中小企業に括いては, 移動率が高く, 従業 員が職場飞定着しにくい事情を考える必要があるとして む, 長期療養者といわず，半年や 1 年病気欠勤すれば失 職するという事実は, 病気休職を保障する期間が短かい といろ調査成績からもうなずけるが，企業体で必要な病 気休職期間を保障されることが望まれる。しかし, 資本 制機藓のなかで, 大企業の垶下にあつて, 企業経営の安
定に腐心する中小企業にとつて，かなりの負担となる面 ああるととは事実であり，この問題の解決には，国が結 核対策や労働政策に括ける課題として，大きくとりあげ る必要があるだろう.

結核回復者の職場復帰は，大企業の一部では，かなり すすめられているよろであるが，中小企業従業者の場合， との点がもつとも不要である. 事実, この調查によると， 退職者の䄪 $30 \%$ が適当な職をむとめていた. これにたい しては，イギリスその他ではすで結核回復者をふくむ 身体障害者を，従業員の何\%相当数雇侓すべしとる特 殊雇侓条例を制定しているが，乙の種の行政的措置を要 望したい.

\section{$\mathbf{V}$ 結 論}

大阪地方に打ける政府管掌被保険者を対象とする結核 集団検診で発見された患者 658 名の検診後 $2 \sim 4$ 年間の 動静と企業体における患者管理の実態を調查した.

1) 結核患者の72\%は化学療法，4\%は外科療法をう けている. 但し化学療法受療期間が短かく，6 力月以下 が $28 \%, 6$ 力月〜 1年が $28 \%$ ありり，半数が 1 年以下で ある.

2）検診後休養した患者は $40 \%$ ，休養した者の半数は 6 力月で職場復帰している.

3 ）休養者の退職事は30\%，そのうち結核を原因とす るものは1 12 ，退職者の $20 \%$ は失職中．また $30 \%$ は適当な 職を求めている.

4 ) 病気休職規定を設けている企業体は65\%. 但しそ の半数は休職保障 1 年以下であり, 病気休職をつづける ことは失職することを意味する.

以上の所見によつて，中小企業においては結核患者に 対する医務管理体制の整備と医務保障の充実がのぞまれ る.

\section{文献}

1）東田敏夫：最近の産業結核の盲点，労働の科学特集 産業結核, 532 541, 1954.

2) 東田敏夫：中小企業における䁃業病，自然，11(10), $38 \sim 45,1956$.

3）労働科学研究所編：日本の競業病，「労働と結核」 198 227, 1959.

4）労㗢省：昭和29年度労衝衛生試験研究費補助全に上 る研究報告集録, 112 117, 1954.

5) 植村敏萨：肺結核のフフターケフー，医学書院， 1955.

6) Raleigh, J. W. : Transaction of the 13th Conference of Tbc. Veteran Administration, 1954. 